(RESEARCH ARTICLE)

\title{
Cassytha filiformis in forests of Jhargram district of West Bengal
}

\author{
Das Debabrata
}

Ecology Laboratory, Department of Botany, Lalgarh Govt. College, Lalgarh, Jhargram, 721516, India.

Publication history: Received on 20 March 2018; revised on 16 July 2018; accepted on 19 July 2018

Article DOI: https://doi.org/10.30574/gscbps.2018.4.1.0023

\begin{abstract}
This communication broadcasts 30 host species of Cassytha filiformis in the forests and jungle of Jhargram district, West Bengal, India. The species parasitizing on some hosts as twiner that perfectly get flowers and fruits during late monsoon and in winter in Junglemahal area of southwest Bengal. Leafless green to crimson yellow plant grows luxuriantly and spreads over small herbs to shrubs even on naturally grown Acacia species in the forest. In social forestry area cashew trees get infected by the twiner in a great extent. Seeds of the plants are green berry like. Pulpy juice of ripe fruits attract birds during late winter so woodland birds migrate into the forest and get feeding advantage as they are frugivorous. The spread of the species is not rapid but the extent of the species is determined by the forest fire. In this article infection\% of the Cassytha filiformis on hosts was studied which ranged between 30-98\%. The fruits are used by frugivorous birds of the forest though it is medicinal plant. The plant is associated with various purposes in ecosystem development so it needs special attention to save the plant to save the biodiversity of the forest.
\end{abstract}

Keywords: Cassytha filiformis; Jhargram district; Infectivity; Importance

\section{Introduction}

Akashbel or benebou is a bengali name of Cassytha filiformis L. which is a obnoxious weed grows gregariously that parasitized on different angiospermic plants including some fern and gymnosperms in the lateritic forests of Southwest Bengal in the state of West Bengal. Its global distribution is widespread though recent reference revealed that 26 vascular plants and spermatophyte were recognised as host of Cassytha filiformis [1]. The genus spreads over 15 paleotropical species but reported 25 species mostly from tropical specific range [2]. According to earlier worker, in India, Cassytha filiformis is common and its distribution is also extended in West Bengal from Bangladeh boarder [3, 4, 5]. It belongs to the family Lauraceae. The plant is called 'love vine' in English. Seeds of this plant are said to be aphrodisiac [6, 7]. Decoction of leaves of Newbouldia laevis (Bignoniaceae) with stem decoction of $C$. filiformis has been taken by Africans to treat the hypertension [8]. It is a species of obligate parasite vine. The species has a pan-tropical distribution encompassing the worldwide distribution and found in Americas, Indo-Malaya, Australasia, Polynesia, and East Africa. In the Caribbean region, it is one of the several plants known as 'love vine' because of its properties and it has a reputation as an aphrodisiac. It is observed that in Ayurveda, Cassytha filiformis and Cuscuta reflexa are important as medicinal plants. As per literature both the plants are controversial drugs in Indian Medicine [9]. Plants used as tonic, alterative, in bilious affections. Some local aborigines used it against cholera. It is also used in chronic dysentery by natives [10,11]. It is also reported as a beneficial medicine against gonorrhoea, kidney ailments and as diuretic [6]. Some alkaloids studied time to time and recorded that the species has anticancer property and used to treat in-vitro trypanosomal activity $[12,13]$.

\footnotetext{
${ }^{*}$ Corresponding author

E-mail address: debabratlalgarh@gmail.com
}

Copyright (C) 2018 Author(s) retain the copyright of this article. This article is published under the terms of the Creative Commons Attribution Liscense 4.0. 


\section{Material and methods}

\subsection{Study area}

District Jhargram lies between $21^{\circ} 52^{\prime}$ and $22^{\circ} 48^{\prime}$ North latitude and $86^{\circ} 34^{\prime}$ and $87^{\circ} 20^{\prime}$ East longitude. On the North it is bordered with the districts like Purulia and Bankura and on the east it is bordered by the river Kangsabati and partly by the river Subarnarekha from the western border of Kharagpur Division of Paschim Medinipur districts. Presently the district has its Blocks viz. Binpur-I, Binpur-II, Jhargram, Jamboni, Gopiballavpur-I, Gopiballavpur-II, Sankrail and Nayagram. It has police stations situated at Belpahari, Binpur, Jamboni, Lalgarh,Jhargram, Gopiballavpur, Nayagram, Beliabara and Sankrail. Its common border found with the state of Odisha on the South and on the west with the Jharkhand state. The major rivers flow inside the Jhargram District are, Kangsavati (Kansai), Subarnarekha and Silabati including Dulung. The district is characterized by lateritic plains and hillocks covered with shrubby vegetation along with patchy sal (Shorea robusta) dominated vegetation here and there. The vegetation is dry deciduous coppice forest which is heterogeneous though some patches have plantation stands like Eucalyptus and Acacias. Plantation stand of Cashew nut (Anacardium occidentale) is another important one found in the western part of the district. Total area of the district is about $3037.64 \mathrm{Km}^{2}$ and the forest area is about 62000 hectare which is fall under Jhargram Forest Division. Following are the places that are studied well for the survey of the host range of Cassytah filiformis. Amlachati-Kalabani is famous and popular site for largest herbal and medicinal plant garden in south Bengal operated by Directorate of Forests, Govt. of W.B. The area has created pleasure and hospitable weather also green environment, green jungle. The distance from Jhargram to the study site is about $7 \mathrm{~km}$ though State Highway-5. Roadside jungle shows bushy Cassytha mat. Kankrajhore is another hill station where enormous pine (Pinus spp.) plantation takes place. It is $25 \mathrm{~km}$ away from Belpahari of Jhargram. The site falls under Mayurjharna Elephant Reserve of West Bengal. A pine forest and lush green sal dominated vegetation observed here. The forest has thick shrubby vegetation that has Cassytha filiformis. During winter one can see the parasite with flowers and fruits. Tapoban is very nearer to Kalmapukuria of Nayagram region adjacent to Odisha. This area is known as birth place of Lab-Kush by Indian Hindu mythology from ancient time. It is situated right bank of Sita nulah stream, which is flowing from high land of lateritic hard head in Nayagram block. The area is a sacred grove in the forest area, which characterized by ecological and rich biodiversity tourist spot. The lush green deep forest has many plants infested by Cassytha filiformis. The site is interconnected from main road Gopiballavpur-Kharikamathani in Jhargram District of West Bengal. Rameswar is nearer to Gopiballavpur. It is located on right bank of Subarnarekha River in Nayagram block, which distance from Jhargram is about 75km along the metallic road. This tourist spot is famous for lord Shiva from Ancient time. Shivaratri, Makar sankranti are main festivals observed by the people. They use the thick bush to make the firing agent. Hatibari-Satma-Jhilli Pakhiralaya are adjacent sites may be regarded as complex study are which is nearer to Jamsolaghat of Balasore. These areas are interconnected with each other and supported by alluvial plains of Subarnarekha basin. The site is characterized by dense forest, rich bio-diversity spot, influenced by the river Subarnarekha, blue water and big reservoir makes a magnificent landscape. The sunrise and sunset point, which are the centre of attractive for tourists in sal-mahul (Shorea robusta-Madhuca indica) forest. Pakhiralay, Satma and Jhilli canal mouth are another eco-tourism spot of this area, which distance from Jhargram is about $60 \mathrm{~km}$ by metallic road via Gopiballavpur. Large bush or canopies covered by Cassytha fiiformis round the year in the shrubberies and in the forest or Jungle are common. Nayagarm-Kaluasarh is another spot nearer to Malam village. This is a forest dominated patch in Nayagram Community Development Block. Kaluasarh is approximately $3 \mathrm{~km}$ away from the forest range Nayagram. The forest has many shrubby species that have been infested by the said species. A big sacred grove attracts many pilgrimages from West Bengal and Odisha. The sal-dominated forest has rich Cassytha vegetation. Belpahari and Laljole are nearer sites have dense sal vehgetation. Forest, lateritic red soil, many hills and hillocks, sacred groves, biodiversity components, rapid and cascade river system and pleasurepeace- hospitable environment along with folk cultural activities of ancient past and host people have created an ecotourism campus in this area. It is a home of many interesting orchid species, habitat for unique flora, fauna. Sal forest shows Cassytha filiformis though lower shrubberies show significant growth of the said species (Figure 1). JhitkaLalgarh is another site under Binpur-I community Development Block of Jhargram District. This area has sal dominated forest aside the Jungle of Bhadutala though in between Jhitka and Bhadutala another patch of vegetation has been demarcated as Pirakata. This forest has sal dominated trees along with many shrubs. Cassytha filiformis found wild and the infection infested by the said species on sal saplings including pole and bole of the said tree. Exotic species like Chromolaena odorata shows infection infected by C. filiformis here (Figure 2). 


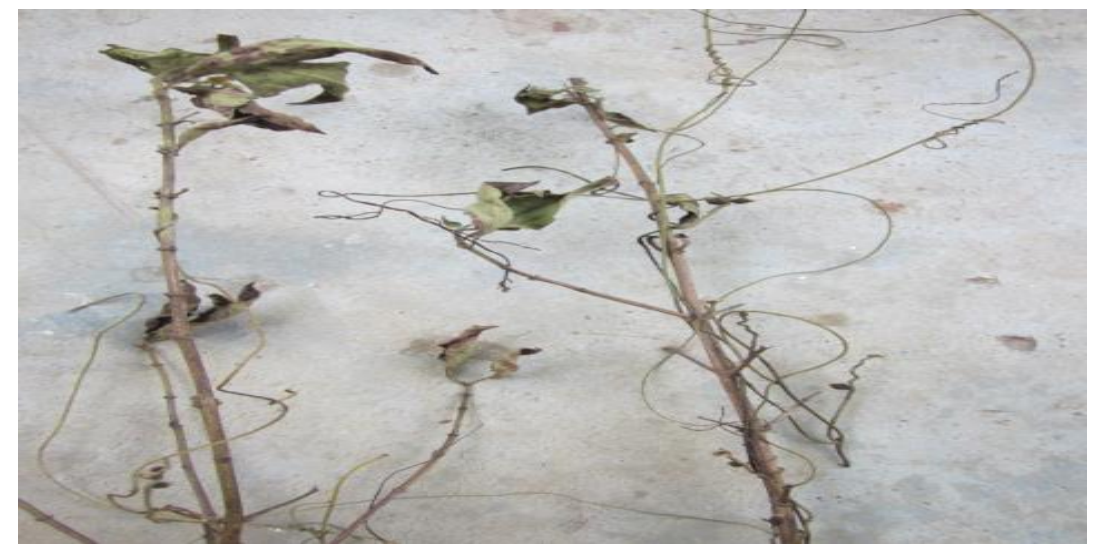

Figure 1 Cassytha filiformis on Mayna laxiflora in the late February, 2018

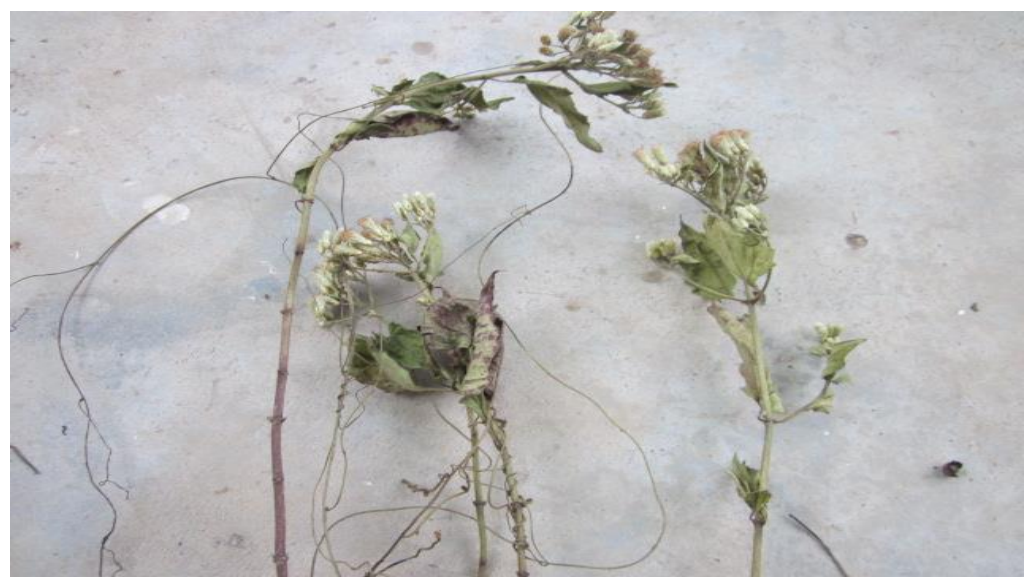

Figure 2 Cassytha filiformis on Chromolaena odorata

Chichira is adjacent to Singhbhum district of Jharkhand. It is under Jamboni block and has a large area of dry deciduous sal forest that has a large number of species along with other admixed vegetation infested by Cassytha filiformis (Figure 3 and 4).

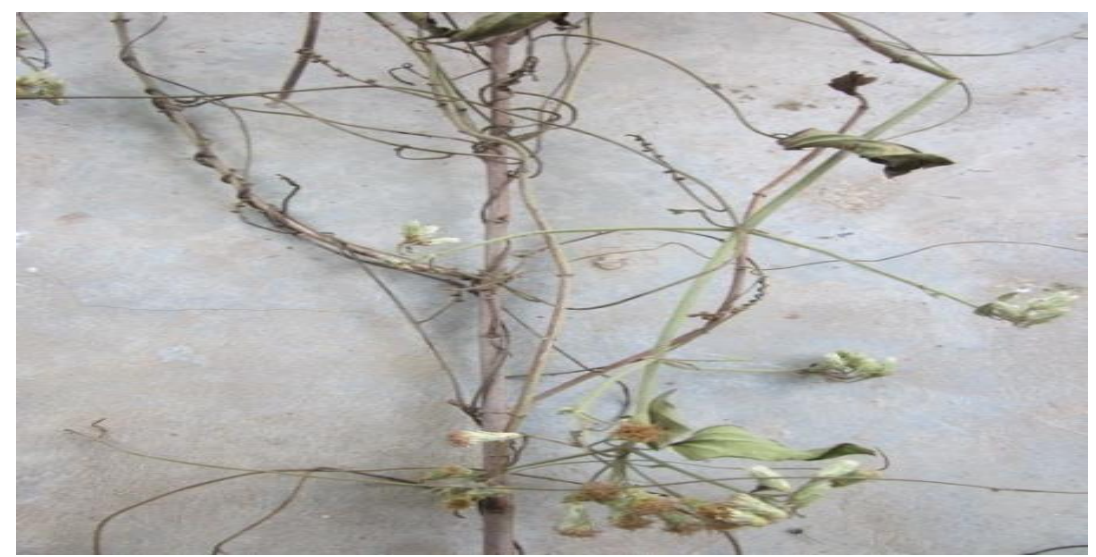

Figure 3 Caytha filiformis on Gardenia gummifera 


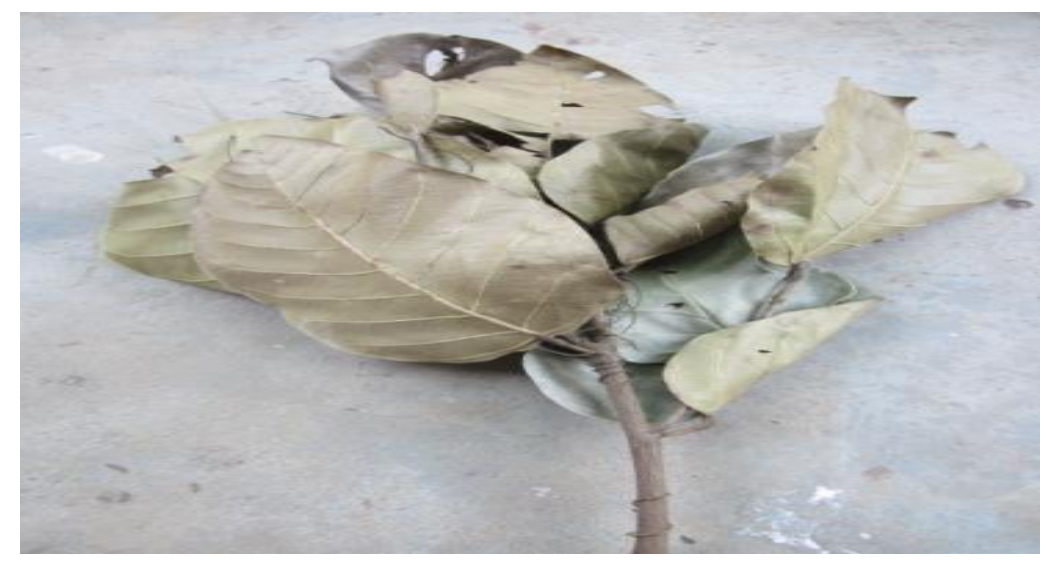

Figure 4 Cassytha filiformis on Sal sapling

Jamboni-Kapgari area has a large strip of Sal vegetation which harbours the said species inside the natural forest, degraded stand and plantation stand which is filled with stem less date palm and Acacias. Once, Lalgarh-Jhitka forest was famous for Royal Bengal Tiger. It is a forest under Jhargram District but it was previously under Paschim Medinipur Forest Division. It is under the Binpur-I community Development Block. Sal dominated forest showed shrubby vegetation (Figure 5) that harbours large and extensive growth of Cassytha filiformis round the year.

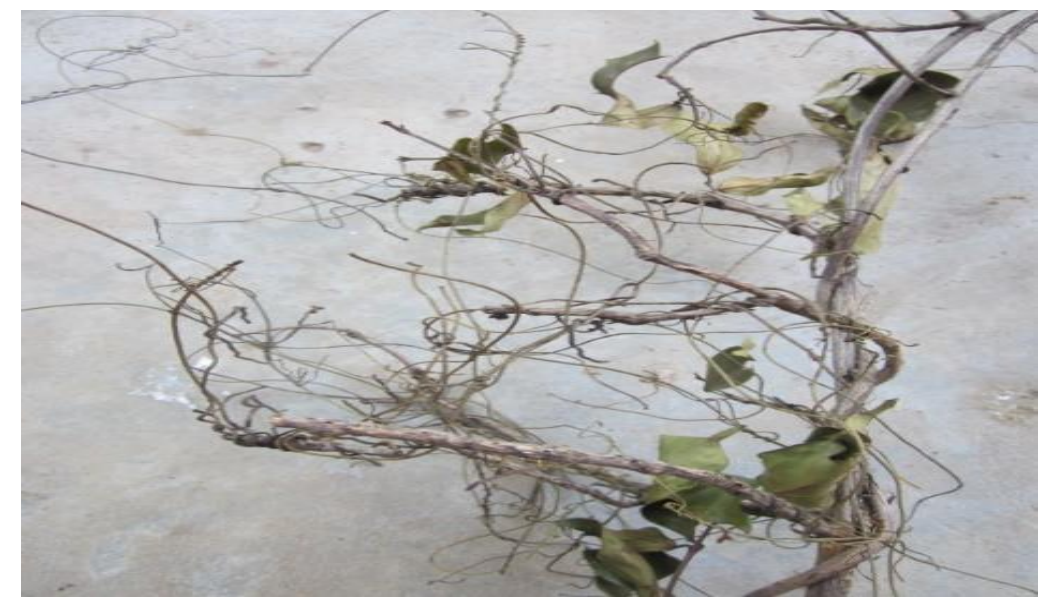

Figure 5 Cassytha filiformis on Combretum decundrum -a woody liana of forest

\subsection{Monitoring of vegetation}

Vegetation of Jhargram is dry sal dominated deciduous forest [14]. Here, monitoring of vegetation and study on Cassytha filiformis has been conducted since 2002 till date. Study done critically in different sites of the forest of Jhargram district but before $4^{\text {th }}$ April, 2017 it was under Paschim Medinipur District of West Bengal. Nikon Coolpix wide 6x Zoom along with Canon Power shot A1200 HD camera and binocular 30 x 60 were used for study. To record the sound and bird call Swipe tab recorder was used. Morning from dawn and evening from dusk were selected for ecosystem study since 2000 to till date. During holiday study was conducted in the sites well to record the roosting, nesting, sitting of birds on Cassytha dominated vegetation even flying and food collection of frugivores were recorded for selected bird species. Tape, Abeny's level and GPS were used for various purposes particularly to study the various lavel of occurrence. Seasonal study was conducted to know the feeding habits of birds on the said species to know the ecosystem status.

\subsection{Study of frequency of species on host species}

Frequency study was done using a standard method used in ecology. In general, 100 plots in 10 study sites (each site with 10 quadarts) were pointed out and studied well to determine the frequency or $\%$ of infection. Each site has been studied seasonally during a large tenure to know the infection on hosts. 


\section{Results and discussion}

The range of host species of Cassytha filiformis is wide. In agricultural land, it is rare in occurrence, though in forests and in social forestry area the species found as semi parasite on almost in all plants except a few exotic tree species and herbs which have pungent odour. Deviation is found in case of Chromolaena odorata which is exotic weed and it has its pungent odour. In West Bengal, Ghosh and Das [4] reported 24 angiosperm species distributed throughout the West Midnapore district. Two years later, Das [5] had reported an extent of host range is lateritic Purulia district that manifests 60 species of 54 genera under 36 families. Out of 36 families, 7 families belong to monocot. After a long gap in between 2000 and 2018 the present author has been reported 30 species of angiosperms (Table 1) which are hosts of Cassytha filiformis in newly formed Jhargram District in West Bengal with great ecological significance.

Table 1 Cassytha filiformis and its host in the newly formed Jhargram District in West Bengal

\begin{tabular}{|c|c|c|c|}
\hline Sr. No. & Scientific Name & Family & $\%$ of infection \\
\hline 1 & Alangium lamarckii & Alangiaceae & 90 \\
\hline 2 & Allophyllus cobbe & Sapindaceae & 70 \\
\hline 3 & Atylosia platycarpa & Fabaceae & 90 \\
\hline 4 & Bridelia retusa & Euphorbiaceae & 75 \\
\hline 5 & Buettneria racemosa & Sterculiaceae & 45 \\
\hline 6 & Casearia tomentosa & Flacourtiaceae & 80 \\
\hline 7 & Cassia fistula & Caesalpiniaceae & 90 \\
\hline 8 & Cassia occidentalis & Caesalpiniaceae & 90 \\
\hline 9 & Cassia tora & Caesalpiniaceae & 80 \\
\hline 10 & Cissus discolour & Vitaceae & 90 \\
\hline 11 & Combretum decundrum & Combretaceae & 98 \\
\hline 12 & Desmodium gangeticum & Fabaceae & 70 \\
\hline 13 & Diciptera bupleuroides & Acanthaceae & 90 \\
\hline 14 & Diospyros melnoxylon & Ebenaceae & 95 \\
\hline 15 & Eupatorium odoratum & Asteraceae & 98 \\
\hline 16 & Flacourtia indica & Salicaceae & 70 \\
\hline 17 & Flemingia chapper & Fabaceae & 60 \\
\hline 18 & Gloriosa superb & Liliaceae & 40 \\
\hline 19 & Holarrhena antidysenterica & Apocynaceae & 90 \\
\hline 20 & Lantana camara & Verbenaceae & 95 \\
\hline 21 & Madhuca indica & Sapotaceae & 98 \\
\hline 22 & Phoenix acaulis & Arecaceae & 80 \\
\hline 23 & Phoenix sylvestris & Arecaceae & 50 \\
\hline 24 & Phyllanthus reticulatus & Euphorbiaceae & 50 \\
\hline 25 & Shorea robusta & Dipterocarpaceae & 98 \\
\hline 26 & Stephania japonica & Menispermaceae & 78 \\
\hline 27 & Streblus asper & Moraceae & 80 \\
\hline 28 & Trema orientalis & Ulmaceae & 50 \\
\hline 29 & Ziziphus jujuba & Rhamnaceae & 30 \\
\hline 30 & Ziziphus oenoplea & Rhamnaceae & 60 \\
\hline
\end{tabular}


The present information is therefore a new vistas to do more on Cassytha in the lateritic district Jhargram which is now need more information to make it complete on the new field of research as it is considered as medicinal plant. Ecologically the said species is important. The plant in the forest ecosystem is beneficial because the plant gets fruits for avifauna. Birds those live in the jungle and others from locality, frequently visit the Cassytha dominated place. They collect fruits of the said plant including fruits from other plants like Allophylus cobbe, Trema orientalis, Vitis pedata and Lantana sp. which are common in Jhargram District. Therefore, it is ecologically important too. In the forest ecosystem, Cassytha filiformis play a significant role to develop avifauna community which secondarily attract other birds and insects as the flowers as attractive and fruits also. Red vented bulbul, sunbird and greater coucal found in the jungle along with thick vegetation underneath the trees like Odina wodier and Terminalia bellerica. The ground vegetation comprised a lot of grassy vegetation along with some sedge that attracts the insects, butterflies, birds and caterpillars. Twining herb Cassytha filiformis starts its infection from small herbs to the upwards and get started infection to the small twigs of various plants. The plants are Shorea robusta, Holarrhena antidysenterica, Mayna laxiflora, Gardenia gummifera, Flacourtia indica, Andrographis paniculata, Olax scandens, Dioscorea bulbifera, Chromolaena odorata, Stephania japonica, Combretum decundrum and Azadirachta indica. All the hosts are medicinal in the local area. After that, it spreads over bushes and on trees of miniature type. Good example is Anacardium occidentale in plantation stand and Acacaia auriculiformis in natural sites including Cassia siamea in degraded stand. The infection and percentage of infection frequency is diverse from site to site. In most of the cases, plant gets $90 \%$ infection though infection intensity is more in winter followed by summer. During monsoon they are found as miniature of structure and rudimentarily present in the said site. So, details of the spread and variations on miniature structure on such species study are essential. In a jungle, the seven sisters (Turdoides striata) feast upon the bushes of plants infested by Cassytha, redvented bulbul (Pycnonotus cafer) eats the fruits, scaly breasted munia (Lonchura punctulata) take rest on the bush, long tail shrike rest on bush and catch its prey from bush while other birds like black drongo, spangled drongo and Jungle myna stay for a moment for their selective prey. Asian pied starling and bank myna frequently found in the site as they choose insects and caterpillars. Doves and rock pigeon (Columba livia) collect sticks from those plants for nesting purpose. As a whole forest ecosystem and woodland habitat drastically fortified its nature as productive characters by adding the said twiner. It is therefore regarded as keystone species of woodland area for many organisms but obviously study and data is essential to come to a point.

Cassytha filiformis is a parasitic plant grows luxuriantly in the lateritic forests of Jhargram district. Here, 30 plant species are more or less infected out of a large number of species in the study site. The said plant is medicinal though no report from the district till date established. People use the plants for fuel or mat preparation only. Birds and insects use these for the purpose of nesting and for food. The growth of the species showed highest during winter and the late winter is the fruiting period. During summer, they tend to dry and only the seeds are present near the hedge. Birds use seeds and use thin fibre for nesting in the jungle. A large number of insects and butterflies have been found in the dense patch of Cassytha filiformis where they show flowers and fruits. Succulent fruits have pulp that attracts red vented bulbul and seven sisters. Due to presence of caterpillars, small reptile like garden lizards are available there which attracts greater coucal. The twining and the structural peculiarity of the vine are very diverse, so that it attracts visitors which help them for pollination. In the jungle, negative impact on vegetation by Cassytha is not yet been reported, but the positive impact placed the species as economically viable but ecologically sustainable. So, need protection of this species in the jungle to protect the forest from manmade fire even from complete destruction which can protect the vegetation of Cassytha filiformis along with other species for biodiversity conservation.

\section{Conclusion}

During monsoon herbaceous vegetation was found maximum and followed by shrubs with profusely covered lianas. The present study revealed that Cassytha filiformis is obnoxious weed which infects on different hosts in the forest of Jhargram district. It is important in the forest because seeds are medicinal and fruits are used by many woodland birds. So, the forest ecosystem generally persist lucid due to presence of the agents and get benefitted as fruits of the said plant which is attractive for frugivorous avifauna. The extents of the species during summer get ruined due to forest fire. So, attention must be paid to protect the forest to protect the important medicinal as well as economic plant $C$. filiformis in the said area.

\section{Compliance with ethical standards}

\section{Acknowledgments}

I acknowledge to Dr. Pampi Ghosh, Assistant professor of Botany, Seva Bharati Mahavidyalaya, Kapgari, Jhargram for her help. Dr. Mrinal Kanti Sathpathy, retired officer of Block Development Office, Jhargram, is thankful for his cordial 
help in various ways to make it ready for a group of readers. I convey my thanks to my beloved sir Dr. V. Santharam, Director, Institute of Bird Studies, Rishi Valley and Andhra Pradesh to make me ready for bird study. Lastly I thanks to my daughter Atmaja Avirupa Das, BCO member, BNHS for her help to identify birds. Deputy Librarian, Vidyasagar University is well acknowledged for the permission to study at Library of the said University. Staffs of Forest department and my students are well acknowledged for time based help.

\section{Disclosure of conflict of interest}

Conflict of interest of author is none. It is only for the ecosystem research in the said area for a group of researcher.

\section{References}

[1] Kokubugata, G and Yokota M. (2012). Host specificity of Cassytha filiformis and C. pergracilis (Lauraceae) in the Ryukyu Archipelago. Bulletin of the National Museum of Nature and Science, 38(2), 47-53.

[2] Willis J. (1948). Dictionary of Flowering Plants and Ferns, Mc Millan, London, UK.

[3] Prain D. (1903). Bengal Plants, Vol.-2, Revised Edition, BSI, 1963.

[4] Ghosh RB and Das D. (1998). Cassytha filiformis-A Census on its host range in the District of Midnapore, West Bengal, Environment and Ecology, 16(2), 485-486.

[5] Das D. (2000). A Preliminary taxonomic survey of host-range of Cassytha filiformis L. (Cassythaceae) in the lateritic district of Purulia, West Bengal, India. Journal of Economic and Taxonomic Botany, 24(2), 467-473.

[6] Praveen M, Srikanth TV, Krupanidhi S and Bharat Kumar R. (2016). In-vitro Studies on phytochemical screening of selected plant species of Vignan's University campus, Vadlamudi, Andhra Pradesh. Journal of Pharmaceutical Sciences and Research, 8(9), 961-966.

[7] Chopra RN, Chopra IC and Verma BS. (1969). Supplement to glossary of Indian medicinal plants. CSIR, New Delhi.

[8] Chopra RN, Chopra IC, Handa KL and Kapoor LD. 1958. Chopra's Indigenous drugs of India. U.N. Dhur and Sons Pvt. Ltd., Calcutta.

[9] Atawodl S Ene-Ojo, Olowrnlyl OD and Dalkwo MA. (2014). Ethnobotanical study of some plants used for the management of hypertension in the lgala speaking area of Koginstate, Nigeria. Annual Research \& Review in Biology, 4(24), 4535-4543.

[10] Shikha S and Amrinder K. (2013). Cuscuta reflexa Roxb. -A Parasitic Plant in Ayurveda, International Journal of Pharmaceutical Research and Bioscience, 2(2), 180-190.

[11] Mythili S, Gajalakshmi S, Sathiavelu A and Sridharan TB. (2016). Pharmacological Activities of Cassytha filiformis: A Review. Asian Journal of Plant Science and Research, 1(1), 77-83.

[12] Wu YC, Chao YC, Chang FR. (1997). Alkaloids of Cassytha filiformis. Phytochem, 46(1), 181-184.

[13] Quetin-Lectercq J, Hoet S, Block S, Wautier MC and Stavigny, C. (2004). Study on Cassytha filiformis from Benin: isolation, biological activities and quantifications of aporphines. Proc.of Bioresources towards Drug Discovery and Development, 81-107.

[14] Das D. (2016). Ecological studies on Jhitka forest under Medinipur forest Division, International Journal for Science and Advance Research in Technology, 2(12), 296-302.

\section{How to cite this article}

Das Debabrata. (2018). Cassytha filiformis in forests of Jhargram district of West Bengal. GSC Biological and Pharmaceutical Sciences, 4(1), 01-07. 